\title{
DETECTION OF THE FATIGUE CRACKS INITIATED NEAR THE RIVET HOLES BY EDDY CURRENT INSPECTION TECHNIQUES
}

\author{
Valentyn Uchanin \\ Karpenko Physico-Mechanical Institute of National Academy of Sciences of Ukraine \\ Naukova str. 5, Lviv, Ukraine, 79060 \\ vuchanin@gmail.com • ORCID: 0000-0001-9664-2101
}

\begin{abstract}
Eddy current (EC) method is considered as most applicable for in-service detection of fatigue subsurface cracks initiated in aircraft multilayer structures near the rivet holes. At the same time, the successful solution of this problem is obstructed by additional noise created by defect-free rivets. All EC inspection techniques for the detection of subsurface cracks around the rivets can be classified into three main groups: 1) static mode - carried out by placing the EC probe concentrically on the rivet head; 2) rotational mode - when the EC probe is rotated around the rivet axle and 2) sliding mode - performed by the movement of EC probe along the rivet line or near it. All these approaches have some advantages and limitations. In this study, known EC techniques for the detection of cracks in multilayer aircraft structures are analyzed. New advanced EC techniques for the detection of fatigue cracks in internal layers of the riveted structures based on different types (ring, sliding, and rotational) probes are presented. The static EC method with developed low-height ring-type probe creates the possibility to detect cracks in the difficult of access areas. The possibility to estimate the length of detected cracks by a ring-type probe is shown. The proposed rotational remote field EC probe can detect as small as $1.0 \mathrm{~mm}$ long cracks under the button-head rivet and $2 \mathrm{~mm}$ thick upper skin with a high signal-to-noise ratio. Therefore, in many aircraft structures, fatigue cracks will be detected before a critical threshold achieved. New EC sliding techniques based on remote field and double differential probes were proposed for the rapid detection of cracks in internal layers of riveted aircraft structures. Remote-field EC probe for reliable detection of fatigue cracks in third and fourth layers of five-layer units was proposed. Another sliding technique based on a double differential EC probe gives the possibility to detect transverse cracks in the second layer without the rivet row area access. The main advantage of developed techniques is high inspection reliability due to the possibility to discriminate the signals created by cracks and defect-free rivets. Presented inspection procedures include the selective signal analysis in the complex plane diagram. Proposed EC inspection techniques were successfully implemented into the aircraft maintenance practice.
\end{abstract}

Keywords: eddy current (EC), EC probe, rivet, multilayer aircraft structure, fatigue crack, operational frequency. 


\section{INTRODUCTION}

The well-timed detection of fatigue cracks is very important for the fail-safe operation of the longterm exploited aircraft structures and for damage tolerance approach application. Therefore, many nondestructive inspection (NDI) procedures are developed and implemented as an important part of modern aircraft maintenance [1-3]. The most susceptible to fatigue damages are the areas around the rivets due to the increased level of stress concentration. In many cases, fatigue cracks are considered as critically dangerous, when cracks are not propagated beyond the rivet head. In general, the number of riveted skins can be greater than two, and fatigue cracks can be located in inner layers of multilayer aircraft units. That is why aircraft maintenance manuals include NDI methods concerned with in-service detection of fatigue cracks originated in the rivet areas when suitable inspection procedures are done by periodically established schedule. Such aircraft inspections are especially needed for aging aircraft when operation time exceeds the primarily prescribed lifetime limit.

The eddy current (EC) method is considered as most applicable for the resolution of this problem without disassembling and rivets removing [3-6]. Due to this attribute, EC inspections can be carried out not only on the repair plant but directly in the field or airport conditions between flights. EC method has many advantages concerned with relative simplicity and productivity of inspection procedures, the possibility to detect cracks situated in internal layers of multilayer aircraft structures, and the low cost of inspection tools. At the same time, the cruel necessity to detect the cracks associated with rivets creates a real challenge because of additional noise originated by defect-free rivets and related signal disfigures. The rivet holes are de facto the material discontinuities even in the case of fatigue crack absence and related signal responses are needed to be suppressed or discriminated.

In this paper, the state of the art of the subject under consideration is analyzed. And advanced EC inspection techniques for detection and sizing of subsurface fatigue cracks in riveted aircrafts units are presented and investigated.

\section{DETECTION OF THE HIDDEN DEFECTS IN THE RIVET AREA - STATE OF THE ART}

Over the past few decades, there has been an intensive development of the EC techniques, related to the detection of the hidden fatigue cracks near the rivet in the multilayer aircraft structures. In our previous works it was indicated that in accordance with the type of the rivet area scanning mode, all EC inspection techniques can be conventionally classified into three main groups $[3,6]$ :

1) Static mode - carried out by placing the EC probe on the rivet head (in most cases coaxially with the rivet axle);

2) Rotational mode - the EC probe is installed on the rivet head and rotated around manually or by means of a special driver.

3) Sliding mode - performed by the movement of the EC probe along the rivet line or near it.

It was mentioned that the major advantages of static inspection techniques are simplicity and relatively high inspection productivity. The disadvantages of static techniques are associated with the influences of a great number of interfering factors, such as variations in the hole or rivet diameter, the changes of the rivet material electrical conductivity, the changes of layers' thickness or the clearance between the layers of the multi-layered units, the changes of the protective coating thickness, etc [3,6]. It can be explained by an absolute type EC probe (referred to as ring or donut probe) application which is sensitive to all these variations. Therefore, in practice sufficiently long (about $5 \mathrm{~mm}$ and more) cracks are detected by this technology application in real field conditions.

The major advantages of rotational inspection techniques are concerned with high sensitivity. The main disadvantage of this technology is associated with relatively low inspection productivity [6]. 
The major advantage of the sliding inspection techniques is its high productivity that exceeds such for the static mode with the ring probe application. But there are some limitations, such as the requirement of the regularity of the rivet location in the row. Therefore, this method is effective when the direction of the possible crack is known in advance and the requirement to the sensitivity is not very high [6].

Among the first publications related to the subject under consideration, there are relevant chapters in ASNT Handbooks $[4,5]$. In these reference issuances, some low-frequency EC techniques possible to detect internal fatigue cracks near rivets in second layer were presented as an exclusive part of aircraft in-service inspection. The main idea of the proposed techniques is to slide the EC probe along a rivet line without removing and to register the signal response changes in the complex plane diagram. The advantages of sliding technique in comparison with the technique in which a circular EC probe is centered over installed rivet were indicated. First of all, sliding techniques offer better inspection sensitivity and reliability. Nevertheless, circular EC probes centered with rivets (named as ring or donut probes) are applied in aircraft routine inspection practice to the present day [6-8]. For example, Boeing proposes to apply the SPO $783 \mathrm{EC}$ probe of ring type (Nortec Inc.) for the detection of the cracks in the wing upper skin of the Boeing 737 aircraft. Similar ring-type EC probes are proposed also by other producers of EC equipment. In the study [8] a shielded ring-type EC probe (6 $\mathrm{mm}$ inner diameter) consisting of driver and sensing coils installed one above another and having an operating frequency in the range from $1 \mathrm{kHz}$ to $20 \mathrm{kHz}$ was employed. During inspection, the ring type EC probe is kept over the rivet heads and the imaginary component of the impedance changes during the probe lift-off are measured and analyzed. An effective EC inspection procedure has been developed for reliable detection of fatigue cracks in countersunk regions of rivets in air-intake structures. Lift-off signal has been utilized to distinguish defective rivets from defect-free rivets. The developed technique has resulted in reliable detection of 0.25 $\mathrm{mm}$ deep defects in $4 \mathrm{~mm}$ and $0.75 \mathrm{~mm}$ deep defects in $5 \mathrm{~mm}$ diameter rivets respectively.

The typical design of the ring-type EC probe is presented in pictorial fig. 1a, wherein: 1 - the sections of the drive coil; 2 - the sections of the sensing coil; 3 - the probe case; 4 - the rivet; 5 - inspected structure. To reduce the unbalanced signal (the output EC probe signal for probe installed on defect-free specimen) the drive and sensing coils are divided into two identical sections [3,6]. So, ring-type EC probe consists of two serially connected sections of the drive coil and two serially differentially connected sections of the sensing. Presented ring-type EC probes can be classified as the EC probe of the absolute compensated type.

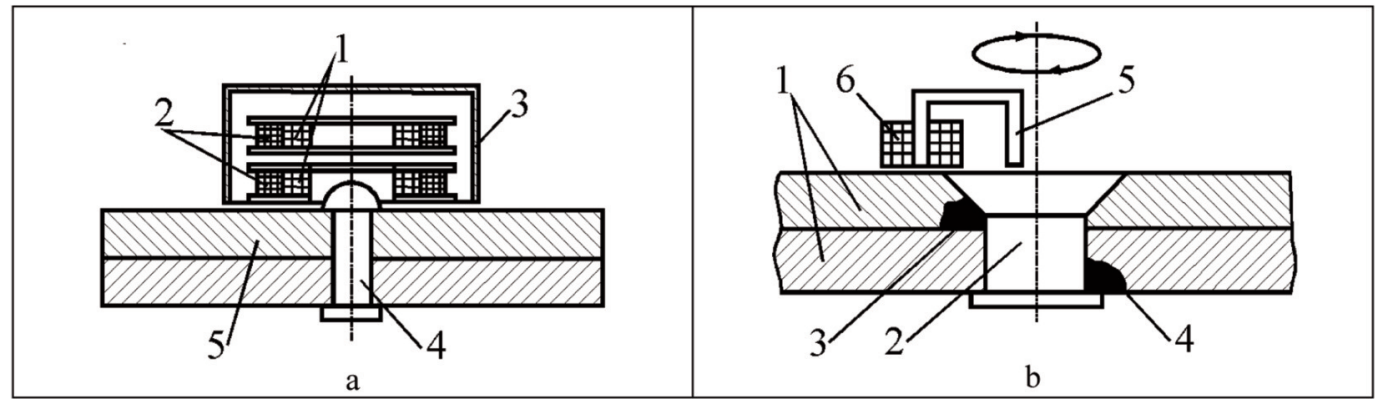

Fig. 1. Ring type [3, 6] (a) and rotational type EC probes [12] (b).

It was mentioned above that the best sensitivity during the inspection of the riveted units is appropriated with the techniques, based on the rotation of the EC probe around the rivet. Several rotational techniques were proposed in [9-12]. One of the proposed EC probe design and scheme of the rotation is presented on pictorial fig. $1 \mathrm{~b}$, wherein: 1 - the skins of two-layer structure; 2 - flush-head rivet; 3 - the crack in the upper skin; 4 - the crack in the bottom skin; 5 - the ferrite core; 6 - sensing EC coil. During the next development, a pulsed eddy current inspection technique when the square 
wave pulse applied to a generator coil and a broad-band Hall-effect sensor instead of sensing coil were introduced [12]. Special scanner was developed to rotate the EC probe around the circumference of the rivet head. Special processing algorithms were applied to generate a target and cross-hair display on the instrument screen. The scanner is moved laterally until it is centered over the rivet. But in these techniques, simple low-penetrated EC probes were applied. This type of EC probes is low sensitive to subsurface cracks, especially to cracks situated in second layers of multilayered aircraft structures.

Several EC techniques which can be conditionally classified as rotational are presented in $[13,14]$. In these inventions, EC probes with circular array coils positioned concentrically over the inspected rivet are proposed. By electronic multiplexing of the array coils, the rotational scanning was achieved in contrast to mechanical scanning used in previously presented techniques.

An effective sliding technique for the detection of fatigue cracks in the rivet area was proposed in US patent [15]. In accordance with this technique, the EC probe is moved along the rivet row line. The sliding-type EC probe consists of one central drive (generator) coil 1 and four sensing coils 2. Sensing coils are placed symmetrically and connected in tandem (fig. 2a) [15]. EC probe is placed on the inspected multi-layer unit 3 with the rivet row 4 . During the inspection, the EC probe is moved along the XX axis that connects the rivets centers. When the crack 5 is appeared, the contours of EC are reallocated (dashed lines in fig. 2a). The EC probe signal response changes are observed in the complex plane (fig. 2b,c). Procedures of the preliminary adjustment consist of EC probe balancing and the orientation of the signal response for EC probe passing along defect-free rivet in a horizontal direction by conventional operation of complex plane rotation.

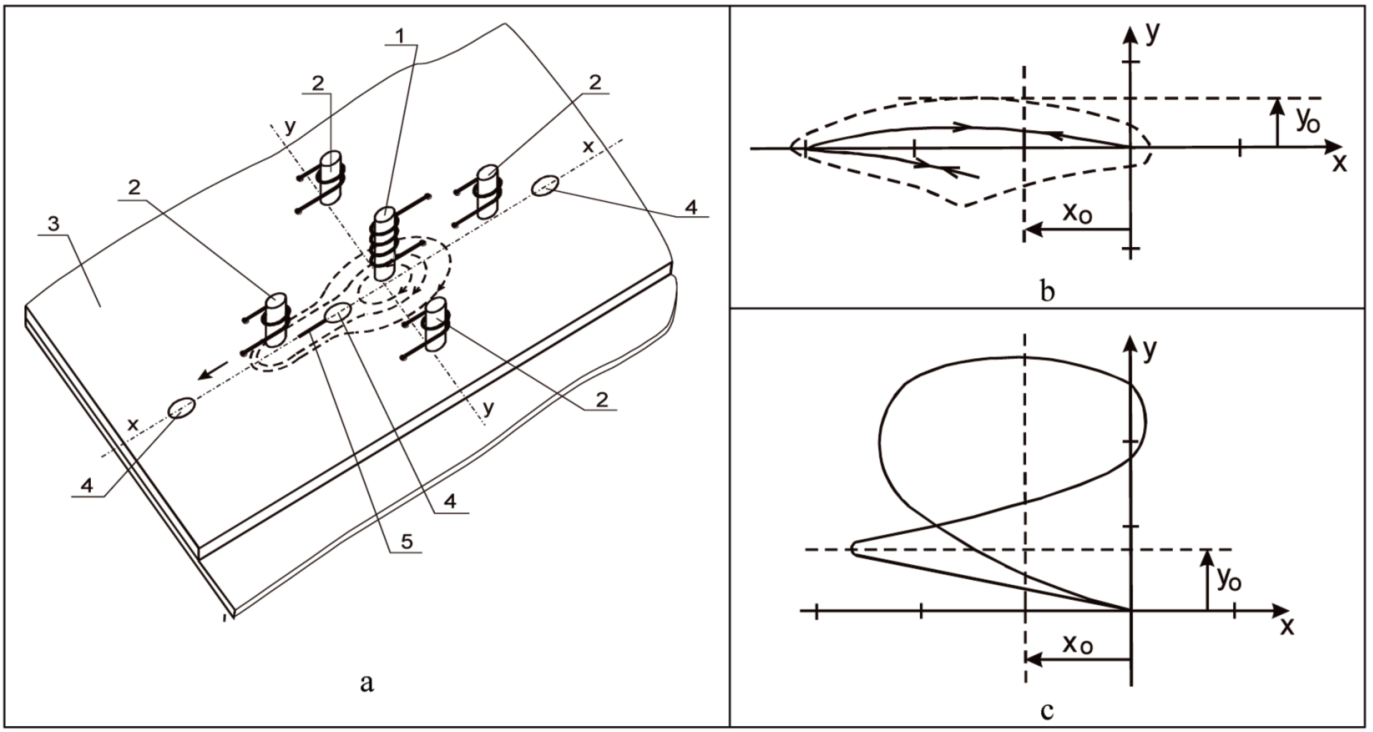

Fig. 2. Sliding EC probe design and scanning scheme for rivet row inspection (a) and signal responses in complex plane for defect-free rivet (b) and for rivet with detected crack (c) [17].

A signal response area for EC probe passing along defect-free rivets (even for EC probe accidental displacement from the central scanning axis) is restricted by the dashed lines (fig. 2b). The derivation of the signal from the defect-free rivet in the vertical direction does not exceed the $y_{0}$ value. Fig. $2 b$ depicts the typical signal response loop from the rivet with the crack. So an operator can easily recognize the signal from crack and signal from defect-free rivets. It is possible also to mark the complex plane sector to regulate the automatic defect alarm: the upper right sector $\left(\mathrm{y} \leq \mathrm{y}_{0}\right.$ and $\left.\mathrm{x} \leq \mathrm{x}_{0}\right)$ is marked by the dashed lines (fig. 2c) [17]. 


\section{DEVELOPMENT AND INVESTIGATION OF IMPROVED EDDY CURRENT INSPECTION TECHNIQUES FOR DETECTION OF CRACKS IN THE RIVETED MULTILAYER STRUCTURES}

\section{Low-height ring type EC probe for detection of cracks in the difficult accessible areas}

As was established above, for static mode realization so called ring (or donut) type EC probes usually are applied (fig. 1a). In some inspection situation, the conventional ring-type EC probes obtained from well-known EC current equipment producers don't enable the detection of cracks in the difficult accessible areas of aircraft (like bulkhead areas) structures because of large EC probe height. That is why a special ring-type EC probe was developed for the inspection of the riveted joints in the Boeing-747 bulkhead areas (fig. 3a) [3]. In this area, the EC probe detects cracks with length more than $5 \mathrm{~mm}$ in the second layer (the upper and bottom layers' thicknesses -1.8 and $0.8 \mathrm{~mm}$ respectively). For flaw detector adjustment, the calibration block fabricated as two riveted aluminum alloy sheets with thicknesses $1.8 \mathrm{~mm}$ and $0.8 \mathrm{~mm}$ was appropriated by Boeing Company. The calibration block has the defect-free rivet (DF) and the rivet with an artificial $5 \mathrm{~mm}$ long electro-discharge slot (D) concerned with the needed detection sensitivity (fig. 3b). Developed EC probe (identified as ARK 1/8) differs from standard ring type EC probes with significantly less height (only $9.5 \mathrm{~mm}$ ). This peculiarity gives the possibility of inspection in bulkhead areas in the "Boeing-747" structures. The real signals of the proposed EC probe in the complex plane are presented in fig. 3c. Before the inspection, the EC probe was installed on the defect-free (DF) rivet of the calibration block (DF in fig. 3b), and the complex plane was rotated to obtain the horizontal direction of lift-off signal (fig. 3c). When the EC probe was situated on the rivet with a defect, the signal point moves from balance point in a vertical direction, as shown in fig. 3c. So, the developed low-height ring-type EC probe demonstrate satisfactory sensitivity to cracks longer than $5 \mathrm{~mm}$ with lift-off signal separation by different direction (phase) in the complex plane.

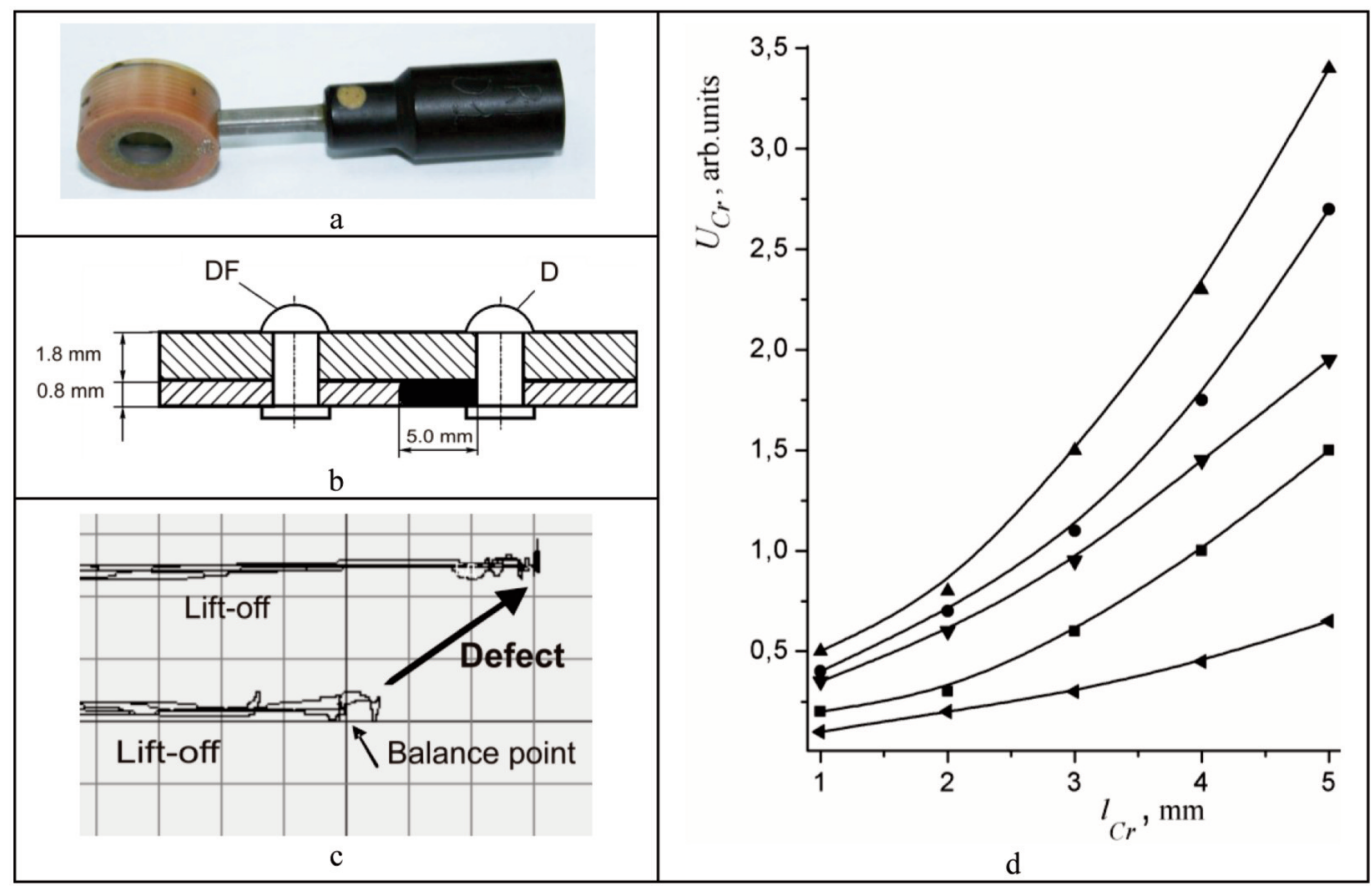

Fig. 3. Ring type EC probe (a), calibration block (b) and obtained signal responses for defect and lift-off (c) and dependence of the signal amplitude $U_{C r}$ on the crack length $l_{C r}$ without the upper skin $(\boldsymbol{\Delta})$ and for the upper skins with thicknesses $0.5(\bullet) 1.0(\nabla)$; $1.5(\boldsymbol{\square})$ and $2.0(\varangle) \mathrm{mm}(\mathrm{d})$. 
To investigate the dependence of ring-type probe signal amplitude on the crack length for different thicknesses of the upper skin, a special $5 \mathrm{~mm}$ thick specimens with electrically discharged like crack $(0.01$ thick) slots were fabricated. The fabricated slots have lengths $1.0 ; 2.0 ; 3.0 ; 4.0$ and $5.0 \mathrm{~mm}$ originated from $5 \mathrm{~mm}$ diameter holes in a radial direction. Dependences of ARK 1/8 type EC probe signal response amplitude $U_{C r}$ in arbitrary units) on the length $l_{C r}$ of the slots initiated from the rivet holes in the bottom skin for different thicknesses of the upper skin are presented in fig. $3 \mathrm{~d}$. Investigations were carried out by the EDDYMAX flaw detector board (produced by Test Maschinen Technik, Germany) in laboratory conditions when the influence of interfering factors mentioned above was excluded. Only in this way, the reliable indications for the cracks as short as $1.0 \mathrm{~mm}$ were obtained.

Presented in fig. 3d result reveals the possibility of the quantitative EC inspection with the length of detected crack estimation. For that, a reasonable correlation must be obtained for the known thickness of the upper skin and applied operational frequency.

Developed ring-type EC probe was implemented into the inspection practice of the International Ukrainian Airlines Company for the detection of fatigue cracks in the hard-to-reach bulkhead area of Boeing-747 (fig. 4). These areas were not inspected previously due to the high height of the conventional EC probe.

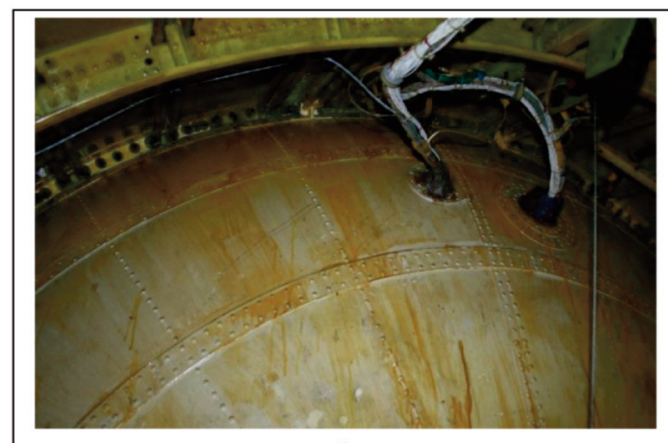

a

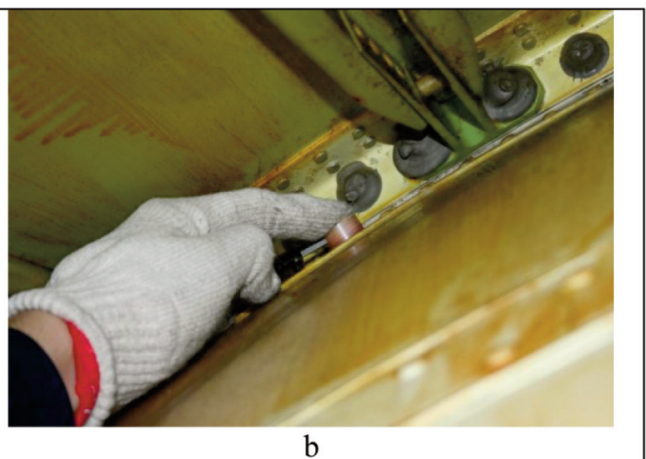

b

Fig. 4. Hard-to-reach bulkhead area of Boeing-747 (a) and inspection procedure of the manual placement of developed ring type EC probe on the rivet head (b).

\section{Rotational inspection technique for detection of fatigue cracks before a critical length will be reached}

As claimed above, the highest sensitivity for the detection of crack near rivets is appropriated with the techniques, based on the rotation of the EC probe around the rivet head. In our development, the original approach for rotational technique creation, based on the remote-field type EC probe application, was proposed [3]. A highly schematic depiction (top and cross-sectional view) of the developed rotational EC probe installed on the riveted lap joint is presented in fig. 5 . The EC probe includes 2 drive coils and 2 sensing coils. Drive coils are connected serially similar to sensing coils to obtain output signal response for probe centered on the rivet. The centering for button-head rivet was carried out by a special hole fabricated in probe case. The special dielectric guide can be applied for flushhead rivets and probe centering. In all cases, this centering is retained during the probe rotation. During the inspection, the EC probe was installed coaxially to the rivet head and rotated after the balance operation. Good centering of the rivet and the EC probe is very essential to minimize the noise produced by changes of the distance to rivet edge during rotation.

The developed rotational EC probe was examined at the operating frequency of $2 \mathrm{kHz}[3]$. The aluminum specimen has a $6 \mathrm{~mm}$ diameter hole with the artificial $0.1 \mathrm{~mm}$ thick slots with the length from 1.0 to $6.0 \mathrm{~mm}$. The specimen was covered with the defect-free skin of $2 \mathrm{~mm}$ thickness with 
the $6 \mathrm{~mm}$ diameter central hole and connected by the rivet to simulate the real aircraft unit. The EC probe signals were investigated in the complex plane of the EDDYMAX flaw detector board during the probe rotation. Obtained signals were stored in PC memory in the TIFF format. All artificial slots in the specimen were detected with a high signal-to-noise ratio. For example, fig. 6 presents the signals in the complex plane for $1.0 \mathrm{~mm}$ (fig. 6a) and $2 \mathrm{~mm}$ (fig. 6b) long cracks through $2 \mathrm{~mm}$ thick upper skin. For the comparison, the noise signals were investigated also to estimate the signal-to-noise ratio. Possible noise was obtained by EC probe rotation around defect-free rivet (fig. $6 \mathrm{c}$ ) and probe lift-off to the height of about $3 \ldots 4 \mathrm{~mm}$ (fig. $6 \mathrm{~d}$ ). As shown in fig. 6 , the signal from the shortest $1 \mathrm{~mm}$ long crack more than $6 \mathrm{~dB}$ exceeds the signal level for different possible noises.

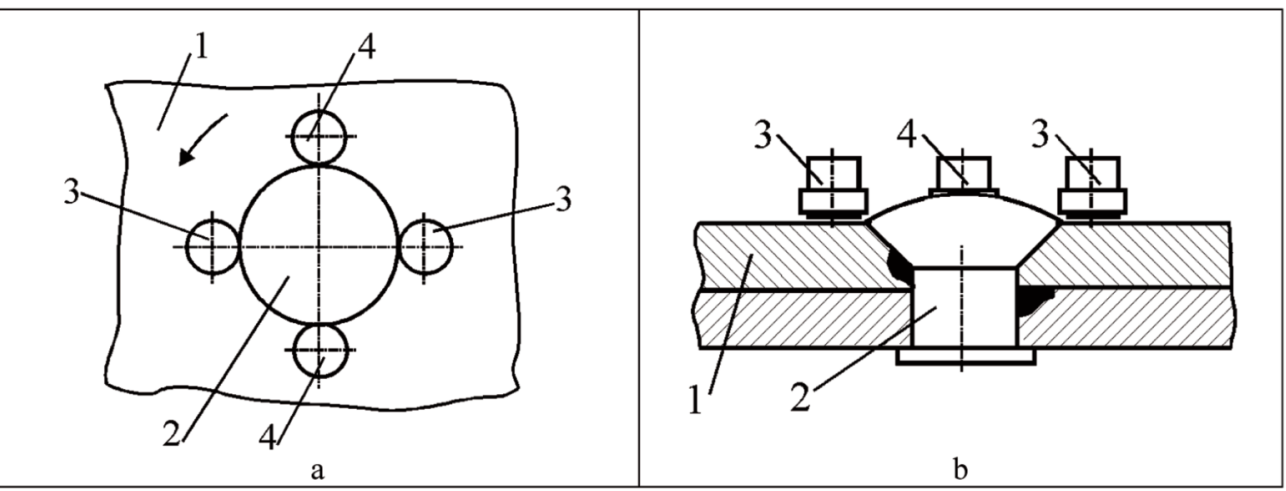

Fig. 5. Top (a) and cross-sectional views (b) of the rotational type EC probes installed on the inspected unit: 1 - inspected unit; 2 - button-head rivet; 3 and 4 - drive and sensing coils respectively.

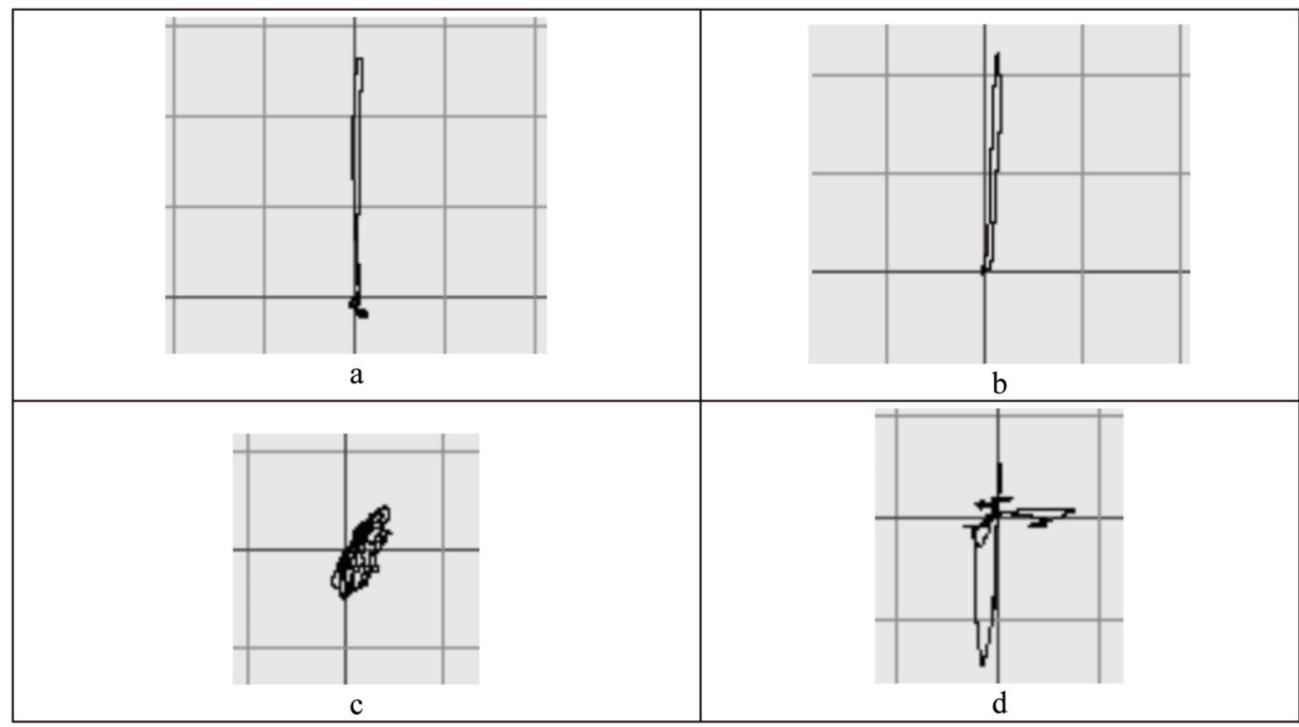

Fig. 6. Signal responses in complex plane for $1 \mathrm{~mm} \mathrm{(a)} \mathrm{and} 2 \mathrm{~mm}$ (b) long cracks situated under the rivet head and $2 \mathrm{~mm}$ thick skin, and structural noise for probe rotated around defect-free rivet (c) and produced by probe lift-off $(\mathrm{d})$.

The sensitivity for $1 \mathrm{~mm}$ long crack (fig. 6a) and for noise (fig. 6c and fig. 6d) are the same. For a $2 \mathrm{~mm}$ long crack (fig. 6b) the sensitivity was $12 \mathrm{~dB}$ decreased. So, it was shown that the crack length 
considerably influences the signal amplitude. Particularly, the signal from the $2 \mathrm{~mm}$ long crack is three times bigger than from the $1 \mathrm{~mm}$ long crack. This result creates the possibility of the quantitative inspection with the crack size estimation after a corresponding calibration.

As a conclusive result, it was revealed that the proposed rotational EC probe can detect as small as $1.0 \mathrm{~mm}$ long cracks under the button-head rivet and $2 \mathrm{~mm}$ thick upper skin. For many aircraft structures, it means that fatigue cracks will be detected before a critical threshold will be reached.

\section{Sliding inspection techniques for rapid detection of fatigue cracks in multilayer aircraft structures}

One of the most difficult problems - the detection of internal cracks propagated from holes in 5-layer units of "Boing-747 aircraft with rows of flush-head rivets [16]. It was needed to detect cracks in third and fourth layers without disassembling. For this purpose, a new remote-field sliding-type EC probe (fig. 7) for inspection on operational frequencies from 0.2 to $4.0 \mathrm{kHz}$ was developed. In this probe, two separate coils are installed on two half-cup ferrite cores to suppress the influence of the primary electromagnetic field on the measuring coil and to minimize the level of the unbalanced signal amplitude. The inspection procedure was tested with special NDT 3049 type specimen produced by US company "NDT Engineering Corporation" and completely adequate the aircraft unit needed to be inspected. The operational frequency of the EDDYMAX type flaw detector was established as low as $500 \mathrm{~Hz}$ for better penetration. Two electro-discharged slots initiated from the rivet hole of the specimen were produced: one $11.4 \mathrm{~mm}$ long slot in the third layer with the $3.6 \mathrm{~mm}$ depth of lying (fig. $8 \mathrm{a}$ ) and second $-16.5 \mathrm{~mm}$ long slot situated in the fourth layer with $6.1 \mathrm{~mm}$ depth of lying (fig. 8b).

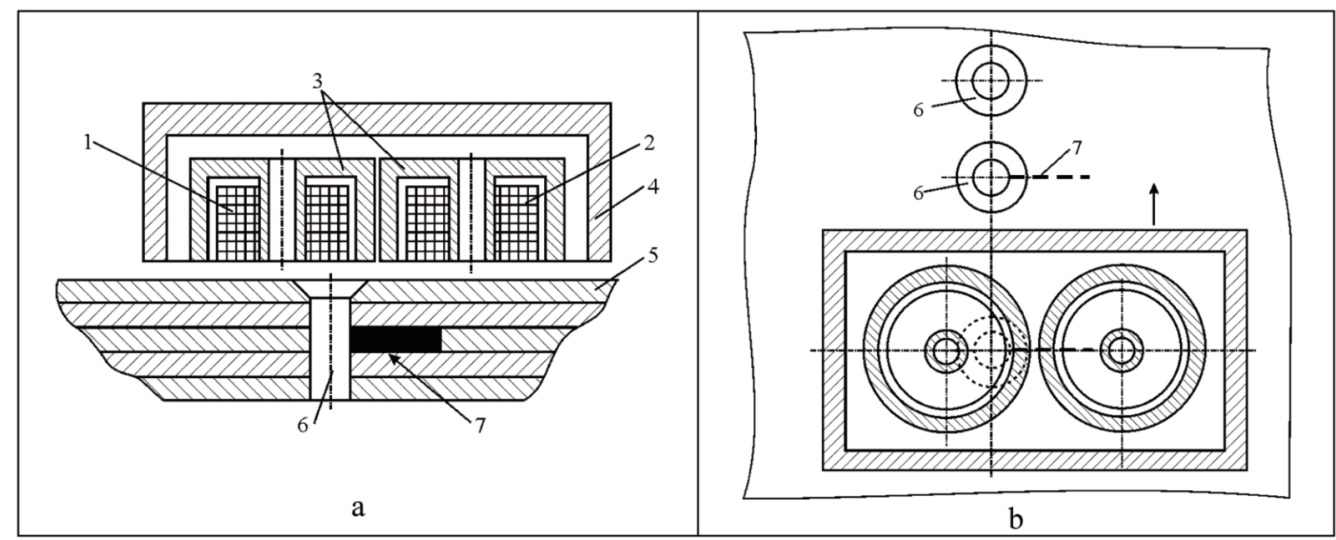

Fig. 7. Inspection scheme for sliding type EC probe: 1 - generator coil; 2 - the measuring coil; 3 - half cup ferrite core; 4 - probe case; 5 - inspected multilayer unit; 6 - rivet; 7 - crack.

In fig. 8c the real signals obtained with the NDT 3049 type specimen application and the typical noise concerned with defect-free rivet influence and lift-off are presented. As seen from this figure, there is the possibility to discriminate the signals obtained from cracks situated in the third (fig. 8a) and fourth (fig. 8b) layers.

The latest EC technique is concerned with the detection of the transverse (concerning rivet row) cracks originated in the rivet area of exploited aircraft in Leonardo Aircraft Division. Proposed sliding technique is based on double differential type EC probe application. Double differential type EC probes were invented few decades ago and were proved as efficient tool for new inspection technologies development in aircraft, railway transport, chemical industry, power engineering and so on [16-19]. These type EC probes have high performance characteristics concerned with the sensitivity, spatial resolution and depth of penetration in combination with small size. But these probes were not applied 
for detection of the fatigue cracks near the rivet holes until recent times. For this application, low frequency double differential type EC probe was developed. Following proposed technique, EC probe scan along the line parallel to the rivet row on some distance such as it is presented in fig. 9, whereon: 1 and 2 - first and second layers of inspected unit respectively; 3 - rivet; 4 - transverse crack; 5 - EC probe. Thereby, the rivet area can be inspected on some distance from the rivet row unlike the conventional EC technique previously presented in fig. 2 [15]. In conventional technique, the sliding EC probe was situated directly above the rivets, and high sensitivity was obtained only to the longitudinal cracks.

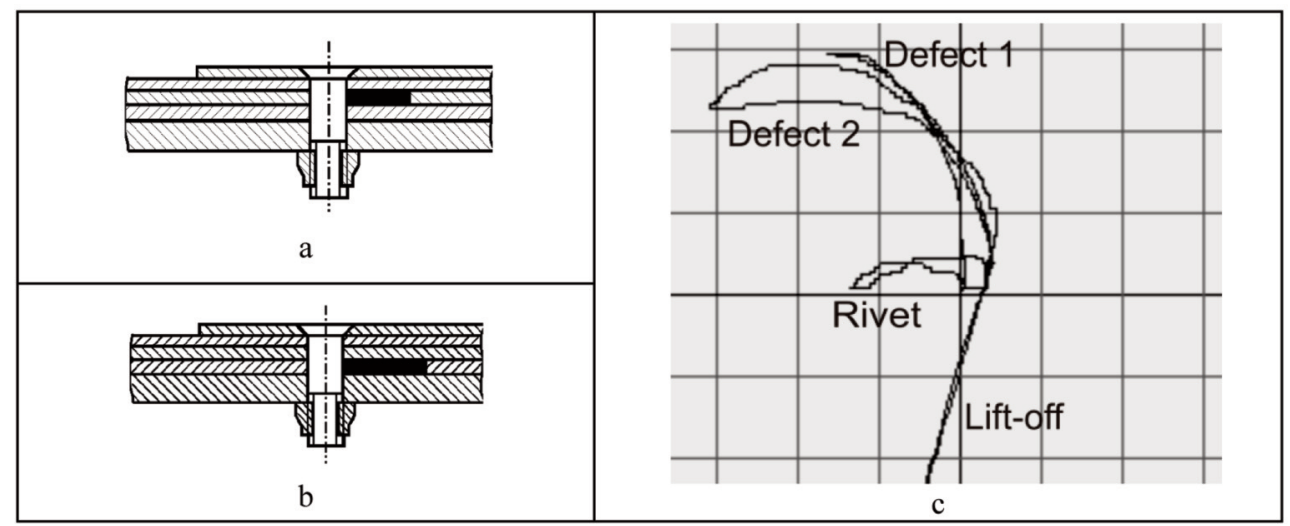

Fig. 8. Location of the cracks in third (a) and fourth (b) layers and respective signals (c).

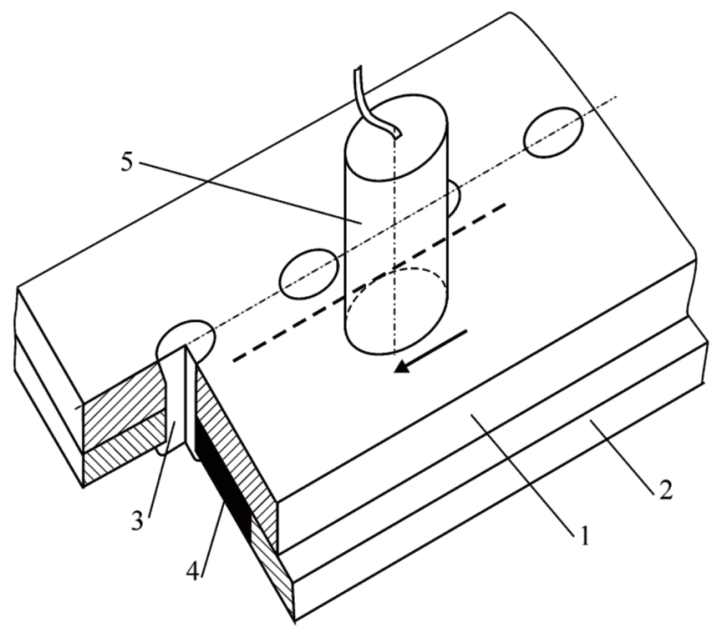

Fig. 9. Detection of the transverse cracks situated in the second layer of aircraft structure.

Possibility of MDF 1502 type EC probe to detect transverse cracks situated in second $3 \mathrm{~mm}$ thick layer in the vicinity of the rivets (fig. 9) were investigated by EDDYMAX flaw detector board. Double differential EC probes create the possibility to enhance the inspection reliability concerned with full separation of EC signals from transverse cracks and defect-free rivets by different direction of signal responses in complex plane. This peculiarity is presented in fig. 10. Here, signals for $6 \mathrm{~mm}$ long crack in second layer in complex plane (fig. 10a) and in time base mode (fig. 10b) are presented. Besides, fig. 10c and fig. $10 \mathrm{~d}$ represent signal obtained from defect-free rivet in complex plane and in time base mode 
respectively. This signal is concerned with obstructive influence of this factor possible to decrease the inspection reliability due to the wrong alarm.

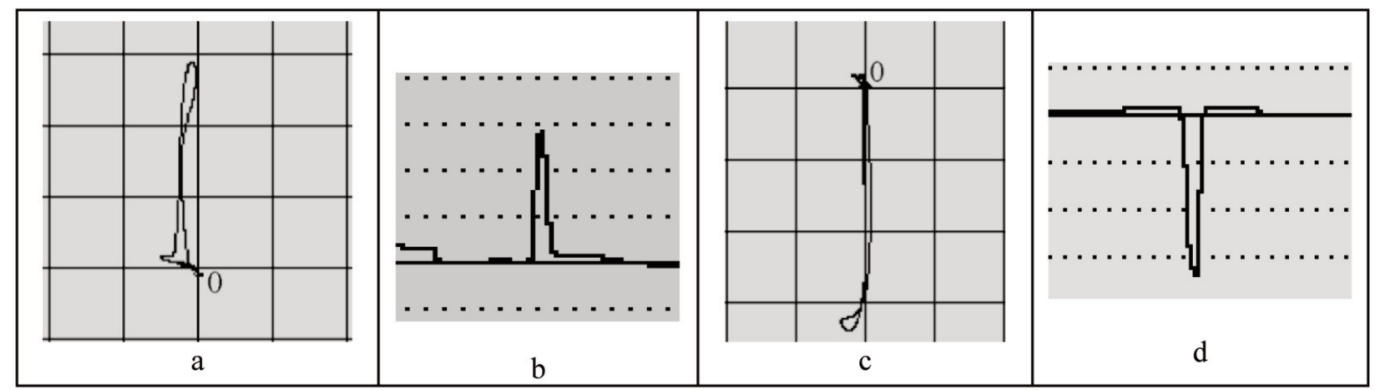

Fig. 10. EC signal responses obtained from the crack in 2-nd layer (a, b) and defect-free rivet (c, d).

As seen from the signals in fig. 10, it is possible to discriminate the signal created by cracks and defectfree rivets by the direction in the complex plane or by a sign of signals in the time base mode. At the same time, high inspection productivity was achieved due to sliding mode application.

\section{CONCLUSIONS}

The low-frequency EC techniques are discussed as most applicable for the detection of hidden fatigue cracks in riveted multilayer aircraft structures in field or airport conditions without disassembling and rivet removing. The advantages and limitations of different EC techniques applied for riveted structure inspection were classified and analyzed.

New advanced EC techniques possible to improve the inspection detectability, reliability, and productivity were proposed and investigated. Besides, the advantage of proposed EC probes and inspection procedures is concerned with the possibility of operation with conventional EC flaw detectors, and additional expenses for inspection instrumentations and operator training are minimized.

The static EC method with developed low-height ring-type probe application creates the possibility to detect cracks in the difficult of access areas. Conventional ring-type probes are not applicable for the detection of fatigue cracks in bulkhead areas due to the large height. The possibility to estimate the length of detected cracks by a ring-type probe is shown.

The proposed rotational remote field EC probe can detect as small as $1.0 \mathrm{~mm}$ long cracks under the button-head rivet and $2 \mathrm{~mm}$ thick upper skin with a high signal-to-noise ratio. So high sensitivity is not available by conventional EC techniques. Therefore, in many aircraft structures, fatigue cracks will be detected before a critical threshold achieved.

The sliding mode estimates as the most preferential when high inspection productivity is needed. New EC sliding techniques based on remote field and double differential probes were proposed for the rapid detection of cracks in internal layers of riveted aircraft structures. Remote-field EC probe for reliable detection of fatigue cracks in third and fourth layers of five-layer units was proposed. Another sliding technique based on a double differential EC probe gives the possibility to detect transverse cracks in the second layer without the rivet row area access.

The main advantage of developed techniques is high inspection reliability due to the possibility to discriminate the signals created by cracks and defect-free rivets. Presented inspection procedures include the selective signal analysis in the complex plane diagram.

Proposed EC inspection techniques were successfully implemented into the aircraft maintenance practice. 


\section{REFERENCES}

[1] Beattie, A., Dahlke, L., Gieske J., Hansche B., Phipps, G., Roach D., Shagam R. and Thompson K., 1994, "Emerging Nondestructive Inspection Methods for Aging Aircraft - Final Report", DOT/FAA/CT-94/31, Federal Aviation Administration, Atlantic City International Airport, N.J.

[2] Goranson, U., 1997, "Fatigue issues in aircraft maintenance and Repairs", Int. J. Fatigue, 20(6), pp. 413-431.

[3] Ostash, O., Fedirko, V., Uchanin, V. Bychkov, S., Moliar O., Semenets, O., Kravets V., Derecha V., 2007, Fracture mechanics and strength of materials, Vol. 5. Strength and durability of airplane materials and structural elements (in Ukrainian), Lviv, Spolom.

[4] McMaster, R.C., and McIntire, P., Mester, M.L., Eds, 1986, Nondestructive testing handbook (second edition), Vol. 4, Electromagnetic testing, American Society for NDT.

[5] Udpa, S.S., More P.O., Eds, 2004, Nondestructive testing handbook (third edition), Vol. 5, Electromagnetic testing, American Society for NDT.

[6] Uchanin, V., 2006, "Eddy current methods for detection of the defects in rivet areas of multilayer aircraft structures" (in Russian), Technical diagnostics and nondestructive testing, 3, pp. 3-12.

[7] Sasi, B., Rao, B.P.C., Jayakumar, T. and Baldev Raj, 2009, "Development of Eddy Current Test Procedure for Non-destructive Detection of Fatigue Cracks and Corrosion in Rivets of Air-intake Structures”, Defence Science Journal, 59(2), pp. 106-112.

[8] Mohd Ali, Imran Hussin and Md Hairudin, 2019, "Defect Analysis on Boeing 737-400 Skin Panel Rivet Row Aft Ward Fuselage” Int. J. Innovative Technology and Exploring Engineering, 8(6S).

[9] Harrison, D.J., 1984, "Detection of surface cracks near a workpiece fastener hole by means of a rotatable probe", U.S. Patent 4445089.

[10] Harrison, D.J., 1985, "Eddy current measurement apparatus for non-destructive testing in the vicinity of fastener", U.S. Patent 4496904.

[11] Harrison, D.J., 1994, Method and apparatus for non-destructive testing of electrically conductive materials, U.S. Patent 5298858.

[12] Harrison, D.J., 1987, "The Detection of Cracks under Installed Aircraft Fasteners by Means of a Scanning Eddy-Current Method", Review of Progress in Quantitative Nondestructive Evaluation, eds. D.Thompson and D. Chimenti, Vol. 6A, pp. 1013-1017.

[13] Sheppard, W., Tam, K., 1995, "Eddy current probe having body of high permeability supporting drive coil and plural sensors", U.S. Patent 5399968.

[14] Hurley, D., Gilmore, R., Young, J., 1996, ”Eddy current surface inspection probe for aircraft fastener inspection, and inspection method", U.S. Patent 5510709.

[15] Arnaud, J., Floret, M., 1984, "Process and device for the detection of cracks in riveted joints using an eddy current probe", U.S. Patent 4677379.

[16] Uchanin, V., 2013, Surface double differential type eddy current probes (in Ukrainian), Spolom, Lviv.

[17] Mook, G., Hesse, O., Uchanin, V., 2007, “Deep penetrating eddy currents and probes”, Materials Testing, 49(5), pp. 258-264.

[18] Uchanin, V., Mook, G., Stepinski, T., 2002, “The investigation of deep penetrating high resolution EC probes for subsurface flaw detection and sizing", Proc. 8-th Europ. Conf. for Nondestructive Testing. 2002. Barcelona. (www.ndt.net).

[19] Uchanin, V., Nardoni, G., 2019, "Detection of cracks in ferrous steel structures: new innovative eddy current techniques”, Procedia Structural Integrity (ESIS), 16, pp. 198-204. 


\title{
WYKRYWANIE PĘKNIĘĆ ZMĘCZONYCH ZAINICJOWANYCH W OTWORACH NITÓW ZA POMOCĄ TECHNIK WIROPRĄDOWYCH
}

\begin{abstract}
Abstrakt
Metodę wiroprądową (EC) uważa się za najbardziej odpowiednią do wykrywania pęknięć podpowierzchniowych zmęczeniowych zapoczątkowanych w konstrukcjach wielowarstwowych w pobliżu otworów nitów stosowanych w statkach powietrznych. Jednocześnie skuteczne rozwiązanie tego problemu jest utrudnione przez dodatkowy hałas wytwarzany przez nity pozbawione wad. Wszystkie techniki inspekcji EC do wykrywania pęknięć podpowierzchniowych wokół nitów można podzielić na trzy główne grupy: 1) tryb statyczny - przeprowadzany poprzez umieszczenie sondy EC koncentrycznie na głowicy nitu; 2) tryb rotacyjny - gdy sonda EC obraca się wokół osi nitu oraz 3) tryb ślizgowy - wykonywany przez ruch sondy EC wzdłuż linii nitu lub w jej pobliżu. Wszystkie te sposoby mają pewne zalety i ograniczenia. W tym badaniu analizowane są znane techniki EC do wykrywania pęknięć w wielowarstwowych strukturach samolotów. Przedstawiono nowe zaawansowane techniki EC do wykrywania pęknięć zmęczeniowych w wewnętrznych warstwach nitowanych konstrukcji opartych na różnych typach (pierścieniowych, przesuwnych i obrotowych) sond. Statyczna metoda EC z opracowaną sondą pierścieniową daje możliwość wykrywania pęknięć w trudno dostępnych obszarach. Pokazano możliwość oszacowania długości wykrytych pęknięć za pomocą sondy typu pierścieniowego. Proponowana sonda obrotowa EC z odległym polem może wykrywać pęknięcia o długości zaledwie 1,0 mm pod nitem z grzybkiem i górną powłokę o grubości $2 \mathrm{~mm} \mathrm{z}$ wysokim stosunkiem sygnału do szumu. Dlatego $\mathrm{w}$ wielu konstrukcjach lotniczych pęknięcia zmęczeniowe zostaną wykryte przed osiagnięciem progu krytycznego. Zaproponowano nowe techniki przesuwania EC oparte na zdalnych sondach polowych i podwójnych sondach różnicowych do szybkiego wykrywania pęknięć w wewnętrznych warstwach nitowanych konstrukcji lotniczych. Zaproponowano sondę EC z odległym polem do niezawodnego wykrywania pęknięć zmęczeniowych w trzeciej i czwartej warstwie pięciowarstwowych konstrukcji. Inna technika przesuwna oparta na podwójnej różnicowej sondzie EC daje możliwość wykrycia pęknięć poprzecznych w drugiej warstwie bez dostępu do obszaru rzędu nitów. Główną zaletą opracowanych technik jest wysoka niezawodność inspekcji dzięki możliwości rozróżnienia sygnałów wytwarzanych przez pęknięcia i nity wolne od wad. Przedstawione procedury inspekcji obejmują selektywną analizę sygnału na złożonym schemacie płaszczyzny. Proponowane techniki inspekcji EC zostały pomyślnie wdrożone w praktyce obsługi technicznej statku powietrznego.
\end{abstract}

Słowa kluczowe: prąd wirowy (EC), sonda EC, nit, wielowarstwowa konstrukcja samolotu, pęknięcie zmęczeniowe, częstotliwość operacyjna. 